\title{
KUNTOUTUS-LEHTI ON TÄRKEÄ KOTIMAINEN TIETEELLIS-AMMATILLISEN KUNTOUTUSTIEDON LEVITTÄJÄ
}

\section{PÄÄKIRJOITUS}

ERJA POUTIAINEN
Jo neljänkymmenen vuoden ajan Kuntoutussäätiön julkaisemana ilmestynyt Kuntoutus on edelleen ainoa kotimainen, pelkästään kuntoutukseen keskittynyt valtakunnallinen tiedelehti. Sinä aikana lehti on etsinyt muotoaan kuntoutuksen ammatillisesta julkaisusta tieteellisempään suuntaan, painotusten vaihdellessa hienoisesti vuosien varrella. Kuntoutus on tieteellisille artikkeleille ainoa koko kuntoutusalan kattava julkaisufoorumi Suomessa. Artikkeleita tarjotaan vuosi vuodelta yhä runsaammin, mikä kertoo paitsi lehden merkityksestä yleisesti ja nuorten tutkijoiden meritoitumisväylänä, myös siitä, että kuntoutuksen tutkimusta on alettu tehdä Suomessa yhä enemmän. Samalla Kuntoutus-lehden sisältö ja asema heijastavat koko kuntoutuksen erityislaatuisuutta: monialaisuutta ja monitieteisyyttä.

Tilaajamaksut ovat muodostaneet ja muodostavat edelleen Kuntoutus-lehden taloudellisen perustan. Näiden lisäksi julkaisutoimintaan on tarvittu muuta rahoitusta. Tähän asti Kuntoutus-lehden julkaisemisen mahdollistanut Sosiaali- ja terveysjärjestöjen avustusosaston (STEA) lehdelle kohdennettu avustusosuus päättyy tämän vuoden lopussa. Tästä syytä lehden toimitus on kuluvan vuoden aikana suunnitellut ja toteuttanut useita sopeuttamistoimenpiteitä sekä etsinyt lehdelle yhteistyökumppaneita. Tavoite on ollut koko ajan selvä: Kuntoutus jatkaa toimintaansa kuntoutusalaa palvelevana tieteellis-ammatillisena julkaisuna.

Lehden monialaisen luonteen vahvistamiseksi sekä jatkon turvaamiseksi lehti on saanut kuluvan syksyn aikana tärkeän yhteistyötahon. Kuntoutuksen tutkimus- ja kehittämisyhdistys Kutke ry on päättänyt syyskokouksessaan 6.10.2017 ryhtyä Kuntoutus-lehden osajulkaisijaksi yhdessä Kuntoutussäätiön kanssa. Kutke ry:lle tärkeitä teemoja ovat kuntoutuksen tieteellisen sekä kehittämistoiminnan edistäminen samoin kuin kuntoutusalan koulutuksen kehittäminen. Kuntoutus-lehden ja Kutken välillä on ollut yhteistyötä jo pidemmältä ajalta. Kuntoutus on Kutken jäsenlehti ja lehden on voinut tilata osana Kutke ry:n jäsenmaksua. Tämä käytäntö säilyy jatkossakin. Suosittelen kuntoutusalan toimijoita liittymään Kutkeen, sitä kautta voi kätevästi tilata myös Kuntoutus-lehden (www.kutke.fi). Lehteä voi toki tilata entiseen tapaan myös suoraan Kuntoutussäätiöstä lehden tilausohjeiden mukaisesti.

Lehden kustantajat Kuntoutussäätiö ja Kutke ry ovat hakeneet avustuksia ja apurahoja lehden varsinaisen toiminnan turvaamiseksi vuoden 2018 alusta. Apurahoja on haettu myös lehden digitaalisen ver- 
sion kehittämiseen. Kutke ry on Tieteellisten seurain valtuuskunnan (TSV) jäsen, ja tämän jäsenyyden puitteissa Kutke on hakenut avustusta tieteelliseen julkaisutoimintaan. Lehden perustoimintaan tarkoitettu TSV:n apuraha on Kuntoutuksen nykymuotoisen jatkumisen kannalta elintärkeä, ja lopputulos tulee vaikuttamaan jossain määrin painetun lehden ulkoasuun. Toivomme lukijoilta ymmärrystä kustannussyistä tarpeellisia, ulkoasuun liittyviä muutoksia kohtaan.

Tämä vuoden 2017 viimeinen numero ilmestyy poikkeuksellisesti kaksoisnumerona. Tieteellisten artikkelien ja katsausten määrä kaksoisnumerossa vastaa kuitenkin kahden erikseen ilmestyvän numeron sisältöjä, emmekä tingi laadusta. Arvioimme kaksoisnumerokokeilun tuloksia myöhemmin.

Tässä numerossa tarjoamme lukijoillemme neljä korkeatasoista tieteellistä artikkelia ja kaksi mielenkiintoista katsausta. Kuntoutusasiakkaan äänen huomioiva tutkimusnäkökulma näyttää vahvistuvan kuntoutuksen tutkimuksessa, mikäli pidämme kriteerinä Kuntoutus-lehden viimeaikaisia tutkimusartikkeleita. Asiakasnäkökulma on keskeisesti esillä kaikissa tämän lehden tieteellisissä artikkeleissa, vaikka tutkimusten kohderyhmät eroavat toisistaan: niitä ovat eri ryhmille suunnatun sopeutumisvalmennuksen asiakkaat, fysioterapeutin suoravastaanotolla käyneet selkäkivusta kuntoutuvat asiakkaat, neuropsykiatrisesti oireilevien lasten huoltajat sekä ikääntyvät työntekijät. Katsauksissa nostetaan kiinnostavasti esiin uusia kuntoutuksen aihepiirejä, kuten luontolähtöistä kuntouttavaa toimintaa sekä kokemuksia julkisen tahon ja järjestöjen yhteistyön tiivistämisestä. Koulutusesittelymme tämänkertaisena aiheena on kuntouttavan sosiaalityön yliopistollinen erikoistumiskoulutus. Kuntoutuksessa tapahtuu -palstalla esittelemme jälleen ajankohtaisia kuntoutuksen tuulia, tässä numerossa voitte lukea esimerkiksi kuntoutuksen uudistamiskomitean uunituoreen raportin linjauksista.

Kuntoutus-lehti jatkaa toimintaansa entiseen tapaan julkaisemalla kuntoutuksen eri näkökulmia edustavia korkeatasoisia tieteellisiä tutkimuksia ja ammatillisia kirjoituksia vuoden 2018 aikana ilmestyvissä neljässä numerossaan.

Erja Poutiainen

Kuntoutus-lehden päätoimittaja 